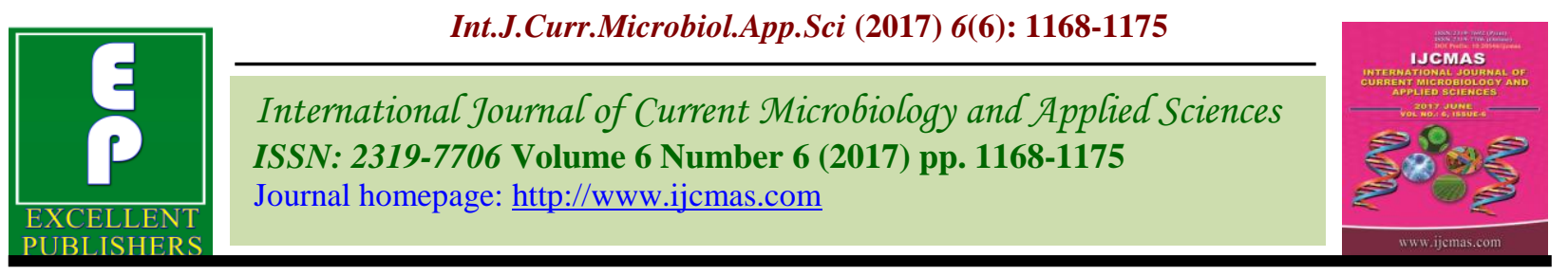

Original Research Article

https://doi.org/10.20546/ijcmas.2017.606.135

\title{
Improvement in Flavor of Gulabjamun Prepared from Camel Milk Khoa
}

\author{
Sachin S. Lad ${ }^{1}$, Bhavbhuti Mehta ${ }^{1}$, S.V. Pinto ${ }^{2}$ and K.D. Aparnathi ${ }^{*}$ \\ ${ }^{1}$ Dairy Chemistry Department, ${ }^{2}$ Dairy Technology Department, SMC College of Dairy Science, \\ AAU, Anand, India \\ *Corresponding author
}

A B S T R A C T

Keywords

Flavor,

Gulabjamun,

Khoa,

Cardamom extract.

Article Info

Accepted:

17 May 2017

Available Online:

10 June 2017
Camel milk is generally produced in very remote areas and far from cities. Therefore, a viable alternate for earning from camel milk appears to convert camel milk into a product with better shelf life. For this purpose manufacture of khoa and its utilization in preparation of sweets like gulabjamun is the most appropriate and viable option. Some defects like poor porosity, insufficient penetration of the sugar syrup, hard central core with doughy feel and typical off taste are the bottlenecks. However, in this paper, we are focused on the flavor improvement in gulabjamun prepared from camel milk khoa. Therefore, present study was undertaken to improve flavor of gulabjamun from camel milk khoa. The objectionable flavor of gulabjamun from camel milk khoa can be successfully masked by the addition of cardamom extract prepared from $1.0 \mathrm{~g}$ of cardamom in $20 \mathrm{ml}$ of water and used for $125 \mathrm{~g}$ formulation along with $54{ }^{\circ}$ Brix sugar syrup as an extract of cardamom ( $3 \mathrm{~g}$ per litre) for soaking the gulabjamun.

\section{Introduction}

Gulabjamun is a popular sweet prepared in all parts of India. Like other sweets, the manufacture of gulabjamun is also largely in the hands of halwa is who adopt small scale batch method. Though there is large variations in the sensory quality of gulabjamun, the most liked product should have brown colour, smooth and spherical shape, soft and slightly spongy body free from both lumps and hard central core, uniform granular texture, mildly cooked and oily flavor, free from doughy feel and fully succulent with sugar syrup. It shall have optimum sweetness. It may or may not contain a piece of cashew nut in the center (Chetana et al., 2004).
Khoa is an indigenous milk product prepared by concentration of milk and is widely used in India and in neighboring countries as a base material for preparation of numerous sweets like Penda, Burfi, Gulabjamun, Kalakand, etc. Khoa is classified into three different categories by BIS (IS: 4883-1980) depending upon its texture and its composition are Pindi, Dhap and Danedar, among these three types, Dhap khoa is preferable for Gulabjamun. This type is characterized by loose and sticky body and smooth texture. It is normally pre-pindi stage and thus contains higher moisture so that balls of smooth surface can be prepared (Kant and Broadwayb, 2017). 
In recent past, work is carried out in this department to prepare the khoa from the camel milk and its characterization. Some preliminary work was carried out to evaluate suitability of the khoa from the camel milk in the preparation of the Gulabjamun and Burfi. Camel milk khoa is not suitable for the preparation of the Burfi but, it shown some promises for its utilization in the preparation of the Gulabjamun. However, results indicated that further work is required to improve the rheological properties and sensory attributes of the gulabjamun prepared from the camel milk khoa. Specific problems were encountered in that gulabjamun were poor porosity of the product affecting the desired penetration of the sugar syrup inside the product and another problem was the typical flavor of the gulabjamun associated with the camel milk.

\section{Materials and Methods}

\section{Collection of milk samples}

All camel milk samples during the investigation were collected from a dromedary herd consisting of 150 animals, kept at Anklav region of Anand district in the Indian state of Gujarat. Raw milk samples were collected at milking time in a clean and dry container. The samples were kept in ice and transported to the laboratory, where they were stored at $4^{\circ} \mathrm{C}$. Samples were collected at random from camel-rearing areas around Taluka of Anand district (State: Gujarat, Country: India). Cow milk and buffalo milk samples were collected as pooled sample from the herd of 65 buffalos and 35 cows from Gopalpura village (District- Anand, State- Gujarat, and Country - India).Milk samples were collected in clean and dry sample bottles and kept at refrigeration temperature. The analysis of milk samples were done at the Dairy Chemistry Department, S.M.C College of Dairy Science, Anand agricultural university, Anand.

\section{Preparation of khoa}

Khoa was prepared separately from all three milks viz. camel, cow and buffalo milks by following the indigenous method of open pan desiccation of milk in a shallow, open, thick bottomed iron pan 'karahi' of 6 litres capacity as described by Srinivasan and Anantakrishnan (1964). Stirring and scraping of the pan surface with iron stirrer was continued till a desired consistency was reached. After cooling, the khoa samples were used for the preparation of the gulabjamun.

\section{Preparation of gulabjamun}

Gulabjamuns were prepared as per the method described by Ghosh et al., (1986). It involves proper blending of khoa, refined wheat flour, suji pre-soaked in water, baking powder and water (optional) to make homogenous and smooth dough. Small amount of water can be added in case of dough is hard and do not roll into small balls. The mix should be made fresh every time. The small balls formed from the dough are deep fried in ghee to golden brown color and subsequently transferred to 54o Brix of sugar syrup maintained at about $60^{\circ} \mathrm{C}$. It takes about 2 hours for the balls to completely absorb the sugar syrup.

\section{Addition of cardamom and saffron extract}

For adding cardamom in dough, the cardamom was extracted in the distilled water. For this purpose, $20 \mathrm{ml}$ of the water taken in the clean beaker, boiled it, and selected level of cardamom/saffron was added to in hot distilled water $\left(80-90^{\circ} \mathrm{C}\right)$. Kept it for 15-20 minutes with continuous stirring. After period of 15-20 minutes, filtered the water with muslin cloth and the obtained flavor extract of cardamom/saffron was added in the dough making instead of adding only pure water. For addition of the cardamom/saffron in the sugar syrup, fresh sugar syrup was 
prepared. When the syrup was hot (about 950C), selected level of the cardamom/saffron was added in the sugar syrup. Kept it for 15 minutes with continuous stirring. After the period of the 15 minutes, sugar syrup was filtered using the muslin cloth. Obtained filtrated syrup was again slightly heated to the temperature of about $60-700 \mathrm{C}$ and then the gulabjamun balls was dipped in that sugar syrup.

\section{Analysis of gulabjamun for sensory quality}

Sensory evaluation of the guidelines was carried out for flavor score9 point hedonic scale (Peryam and Pigrim, 1957).

\section{Results and Discussion}

The serious bottleneck in utilization of camel milk khoa for preparation of gulabjamun was typical off taste associated with the camel milk which carried forward to the gulabjamun. In order to improve the flavor characteristics of the Gulabjamun use of cardamom, saffron as well as cardamom and saffron in combination was attempted.

To evaluate the effect of cardamom, saffron and their combination on flavor of gulabjamun, the samples of gulabjamun were prepared from blend of camel milk khoa and buffalo milk khoa (70:30, w/w) along with use of suji and maida $(5: 15, \mathrm{w} / \mathrm{w})$.

\section{Effect of cardamom on flavor of gulabjamun}

For testing efficacy of cardamom to improve flavor score of gulabjamun, work was required to access compatibility of the cardamom flavor to select suitable mode for its incorporation and optimum rate of the addition. There were three different possible modes for incorporation of cardamom in gulabjamun. It could be incorporate in sugar syrup, dough and sugar syrup as well as dough. For incorporation of cardamom in dough, extracts from $0.05,1.0$ and $2.0 \mathrm{~g}$ per $20 \mathrm{ml}$ water were prepared and extract so obtained was used for preparation of dough for the gulabjamun. In preliminary trials, it was found that the extract from $0.5 \mathrm{~g}$ of cardamom was weak in imparting sufficient flavor to the product. On the other hand, the extract from $2.0 \mathrm{~g}$ of cardamom gave slightly harsh flavor. The extract from $1.0 \mathrm{~g}$ of cardamom provided acceptable flavor to the product. Therefore, use of cardamom extract from $1.0 \mathrm{~g}$ in $20 \mathrm{ml}$ of water was fixed for further study.

For incorporation of cardamom in sugar syrup, $0.1,0.2,0.3$ and $0.4 \mathrm{~g}$ cardamom per $100 \mathrm{ml}$ sugar syrup were prepared and sugar syrup so obtained was used for soaking of the gulabjamun. In preliminary trials, it was found that the sugar syrups from 0.1 and $0.2 \mathrm{~g}$ of cardamom were weak in imparting sufficient flavor to the product. On the other hand, the sugar syrup from $0.4 \mathrm{~g}$ of cardamom gave slightly harsh flavor.

The sugar syrup from $0.3 \mathrm{~g}$ of cardamom provided acceptable flavor to the product. Therefore, use of cardamom at the rate of 0.3 $\mathrm{g}$ per100 $\mathrm{ml}$ of sugar syrup was fixed for further study.

After optimizing the rate of cardamom for use in dough and sugar syrup, in next step for testing the cardamom for improving flavor of gulabjamun, both the approaches of incorporating of cardamom in gulabjamun were applied together.

For this purpose cardamom was incorporated in dough as well as sugar syrup at their respective optimized rates. All the samples of gulabjamun were subjected to sensory evaluation for flavor score using 9-point hedonic scale. Samples of gulabjamun without use of cardamom were taken as control. 
The results obtained are given in table 1 . Results of the flavor score of the gulabjamun obtained from sensory evaluation revealed that the gulabjamun prepared from camel milk khoa without addition of cardamom was below acceptable level (score < 6).

When cardamom was incorporated during the preparation of the dough, the score of the gulabjamun was significantly improved. The average flavor score of the gulabjamun samples was falling between like moderately and like very much. Similarly, incorporation of cardamom in sugar syrup used for dipping the gulabjamun also significantly improved the flavor score of gulabjamun to similar extent.

The flavor score of the gulabjamun was further improved when cardamom was incorporated in both dough as well as sugar syrup. In this case flavor score of the gulabjamun reach to a level between like very much and like extremely.

Here, improvement in the flavor score of the gulabjamun was significantly higher compared to incorporation of cardamom only in dough or only in sugar syrup.

Thus, the results revealed that, addition of cardamom in dough as well as sugar syrup gave the maximum improvement in flavor score of the resultant gulabjamun.

Ghosh et al., (1984) formulated a ready to use gulabjamunmix powder (GMP) and the method of Gulabjamun preparation standardized from roller dried skimmed milk (SMP). The authors tried addition of cardamom powder at $0.05,0.10$ and 0.20 per cent of dry mix. Addition of 0.10 per cent cardamom powder was appropriate to mask the powdery and doughy taste in the gulabjamun while at 0.20 per cent rate of addition, the flavor was slightly higher. Thus, the results obtained in present study about effect of cardamom in masking of flavor in gulabjamun prepared from camel milk khoa was in general agreement with the results reported by these authors.

The difference in amount of cardamom required in the present study and the amount reported by these authors might be attributed to difference in type of milk used in the study. The khoa from camel milk had more pronounced off flavor compared to the cow and/or buffalo milk powder used by this author. Use of cardamom powder as a flavoring agent has also been reported by Ghosh et al., (1986) in khoa based gulabjamun mix.

\section{Effect of saffron on flavor of gulabjamun}

For testing efficacy of saffron to improve flavor score of gulabjamun work was required to access compatibility of the saffron flavor, to select suitable mode for its incorporation and optimum rate of the addition. There were three different possible modes for incorporation of saffron in gulabjamun. It could be incorporate in sugar syrup, dough and sugar syrup as well as dough. For incorporation of saffron in sugar syrup, 0.1, $0.2,0.3$ and $0.4 \mathrm{~g}$ saffron per $100 \mathrm{ml}$ sugar syrup were prepared and sugar syrup so obtained was used for soaking of the gulabjamun. However, it was noticed that saffron imparted yellow colour to the sugar syrup (as shown in Figure 1) gave somewhat unnatural appearance to the surface of gulabjamun. It was also unable to improve the flavor of the gulabjamun. Therefore, this approach of using saffron in sugar syrup was dropped from further study. 
Table.1 Effect of incorporation of cardamom on flavor score of gulabjamun

\begin{tabular}{|l|c|c|}
\hline \multirow{2}{*}{$\begin{array}{c}\text { Mode of incorporation of } \\
\text { cardamom }\end{array}$} & \multicolumn{2}{c|}{ Flavor score } \\
\cline { 2 - 3 } & Range & Average \\
\hline Control & $5.66-6.00$ & 5.85 \\
\hline Dough & $7.16-7.41$ & 7.29 \\
\hline Sugar syrup & $7.83-7.91$ & 7.85 \\
\hline Dough and sugar syrup & $8.16-8.58$ & 8.41 \\
\hline \multicolumn{2}{|c|}{0.06} \\
\hline SEm & \multicolumn{2}{|c|}{0.18} \\
\hline CD $_{(\mathbf{0 . 0 5})}$ & \multicolumn{2}{|c|}{1.50} \\
\hline Test & \multicolumn{2}{|c|}{} \\
\hline CV \% & \multicolumn{2}{|c|}{} \\
\hline
\end{tabular}

Table.2 Effect of incorporation of saffron on flavor score of gulabjamun

\begin{tabular}{|l|c|c|}
\hline \multirow{2}{*}{$\begin{array}{c}\text { Rate of addition of saffron } \\
\text { (gram/125 g dough) }\end{array}$} & Range & Average \\
\cline { 2 - 3 } Control & $5.33-5.74$ & 5.48 \\
\hline 0.1 & $7.58-7.75$ & 7.64 \\
\hline 0.2 & $7.50-7.83$ & 7.73 \\
\hline 0.3 & $7.50-7.83$ & 7.66 \\
\hline 0.4 & $7.41-8.00$ & 7.69 \\
\hline \multicolumn{2}{|c|}{0.07} \\
\hline SEm & \multicolumn{2}{|c|}{0.23} \\
\hline CD $(\mathbf{0 . 0 5 )}$ & \multicolumn{2}{|c|}{2.07} \\
\hline Test & \multicolumn{2}{|c|}{} \\
\hline CV \% &
\end{tabular}

Table.3 Effect of cardamom plus saffron on flavor score of gulabjamun

\begin{tabular}{|c|l|c|c|}
\hline \multirow{2}{*}{ Code } & \multicolumn{1}{|c|}{ Samples of gulabjamun } & \multicolumn{2}{c|}{ Flavor score } \\
\cline { 2 - 4 } & \multicolumn{1}{|c|}{ Range } & Average \\
\hline A & Control & $4.58-5.50$ & 5.00 \\
\hline B & Cardamom in sugar syrup and in dough & $8.42-8.58$ & 8.50 \\
\hline C & Cardamom in sugar syrup and saffron in dough & $6.83-7.25$ & 7.04 \\
\hline D & Cardamom in sugar syrup and saffron + cardamom in dough & $7.33-7.75$ & 7.54 \\
\hline \multicolumn{2}{|c|}{} \\
\hline SEm & \multicolumn{2}{|c|}{0.12} \\
\hline CD $(\mathbf{0 . 0 5 )}$ & 0.37 \\
\hline Test & \multicolumn{2}{c|}{$*$} \\
\hline CV \% & 3.40 \\
\hline
\end{tabular}


Fig.1 Incorporation of saffron to sugar syrup imparted typical yellow colour

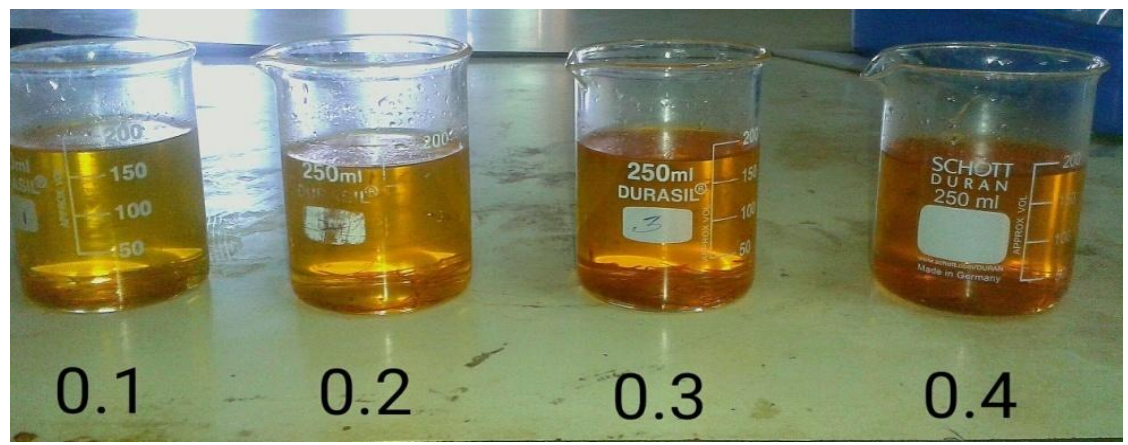

For incorporation of saffron in dough, extracts from $0.1,0.2,0.3$ and $0.4 \mathrm{~g}$ per $20 \mathrm{ml}$ water were prepared and extract so obtained was used for preparation of dough for the gulabjamun. All the samples of gulabjamun were subjected to sensory evaluation for flavor score using 9-point hedonic scale. Samples of gulabjamun without use of cardamom were taken as control. The results obtained are given in table 2 .

Results of the flavor score of the gulabjamun obtained from sensory evaluation revealed that the gulabjamun prepared from camel milk khoa without addition of saffron was below acceptable level (score < 6). When saffron was incorporated during the preparation of the dough, the score of the gulabjamun was significantly improved. The average flavor score of the gulabjamun samples was falling between likes moderately and like very much. The maximum score was obtained at $0.2 \mathrm{~g}$ saffron in the batch of $125 \mathrm{~g}$ total ingredients. However, difference between flavor score of gulabjamun prepared with different rated of saffron (i.e. 0.1, 0.2, 0.3 and $0.4 \mathrm{~g}$ ) was statistically at par. Therefore, addition of saffron at the rate of $0.1 \mathrm{~g}$ was selected for further study.

Saffron is highly flavorful substance and it was expected to improve the flavor of the gulabjamun to very high level, such as like extremely. However, it was evident from the result that, flavor could be improved only below the level of like very much. The possible reason for failure in boosting the flavor score of the product might be attributed to alternation in aroma and taste of saffron due to high heat treatment (about $130^{\circ} \mathrm{C}$ ) and encountered during frying process.

No work has been reported so far for use of saffron in the preparation of gulabjamun in general or from khoa from camel milk. Therefore, results obtained in present study could not be compared with the information in the literature.

\section{Effect of cardamom plus saffron on flavor of gulabjamun}

In further attempts to improve flavor of gulabjamun, combination of cardamom and saffron incorporation was evaluated for their possible synergistic effect. Therefore, both cardamom and saffron were incorporated in gulabjamun in different combinations as described below. For this purpose cardamom was incorporated in dough and/or sugar syrup at their respective optimized rates, along with $0.1 \mathrm{~g}$ saffron extract only in dough.

All the samples of gulabjamun were subjected to sensory evaluation for flavor score using 9point hedonic scale. Samples of gulabjamun without use of cardamom were taken as control. The results obtained are given in table 3 . 
Results of the flavor score of the gulabjamun obtained from sensory evaluation revealed that the gulabjamun prepared from camel milk khoa without addition of cardamom and/or saffron was below acceptable level (score < 6). However, the results also revealed that, addition of cardamom in dough as well as sugar syrup gave the maximum improvement in flavor score of the resultant gulabjamun. The flavor score obtained for the gulabjamun was significantly lower in case of cardamom as well as saffron both was added in combination (Sample C and D), compared to the gulabjamun obtained from the incorporation of cardamom in dough as well as sugar syrup (Sample B).

The above findings revealed that, use of cardamom and saffron together in gulabjamun resulted into antagonistic effect rather than synergistic effect. The lower sensory score obtained on use of cardamom and saffron together in gulabjamun was attributed to alteration in aroma and taste of the product. The actual taste and aroma imparted by this combination was somewhat non-compatible with the product. Such alterations might be attributed to some possible interaction and/or reactions between the flavoring compounds of cardamom and that of the saffron.

No work has been reported so far for use of cardamom and saffron in combination to improve the flavor of gulabjamun in general or from khoa from camel milk. Therefore, results obtained in present study could not be compared with the information in the literature.

For incorporation of cardamom in dough, extracts from $0.05,1.0$ and $2.0 \mathrm{~g}$ per $20 \mathrm{ml}$ water were prepared and extract so obtained was used for preparation of dough for the gulabjamun. The extract from $1.0 \mathrm{~g}$ of cardamom provided acceptable flavor to the product. Therefore, use of cardamom extract from $1.0 \mathrm{~g}$ in $20 \mathrm{ml}$ of water per $125 \mathrm{~g}$ formulation was fixed. Similarly, for incorporation of cardamom in sugar syrup, $0.1,0.2,0.3$ and $0.4 \mathrm{~g}$ cardamom per $100 \mathrm{ml}$ sugar syrup were prepared.

The sugar syrup from $0.3 \mathrm{~g}$ of cardamom provided acceptable flavor to the product. For incorporation of saffron in sugar syrup, 0.1, $0.2,0.3$ and $0.4 \mathrm{~g}$ saffron per $100 \mathrm{ml}$ sugar syrup were prepared and sugar syrup so obtained was used for soaking of the gulabjamun. However, it was noticed that saffron imparted yellow colour to the sugar syrup gave somewhat unnatural appearance to the surface of gulabjamun. It was also unable to improve the flavor of the gulabjamun. Similarly, for incorporation of saffron in dough, extracts from $0.1,0.2,0.3$ and $0.4 \mathrm{~g}$ per $20 \mathrm{ml}$ water were prepared and extract so obtained was used for preparation of dough for the gulabjamun.

The difference between flavor score of gulabjamun prepared with different rated of saffron (i.e. 0.1, 0.2, 0.3 and $0.4 \mathrm{~g}$ ) was statistically at par. Moreover, addition of saffron in combination with cardamom resulted into antagonistic effect rather than synergistic effect, since it altered the aroma and taste of the product.

\section{References}

BIS. 1980. IS: 4883: Indian standards Specification for khoa. New Delhi.

Chetana, R., Manohar, B. and Reddy, S.R.Y. 2004. Process optimization of Gulabjamun, an Indian traditional sweet, using sugar substitutes. European Food Res. Technol., 219: 386.

Ghosh, B.C., Rajorhia, G.S. and Pal, D. 1984. Formulation and storage studies of gulabjamun mix powder. Indian $J$. Dairy Sci., 37: 362. 
Ghosh, B.C., Rajorhia, G.S. and Pal, D. 1986. Complete Gulabjamun mix. Indian Dairyman, 38: 279.

Kant, R. and Broadwayb, A. 2017. Enhancement of functional properties of Gulabjamun by soya fortified milk. The Pharma Innovation J., 6: 94.
Peryam, D.R. and Pilgrim, F.J. 1957. Hedonic scale method of measuring food preferences. Food Technol., 9-14.

Srinivasan, M.R. and Anantakrishnan, C.P. 1964. Milk products of India. Indian Council of Agricultural Research, New Delhi, 88.

\section{How to cite this article:}

Sachin S. Lad, Bhavbhuti Mehta, S.V. Pinto and Aparnathi, K.D. 2017. Improvement in Flavor of Gulabjamun Prepared from Camel Milk Khoa. Int.J.Curr.Microbiol.App.Sci. 6(6): 11681175. doi: https://doi.org/10.20546/ijcmas.2017.606.135 